Cite this: RSC Adv., 2019, 9, 15749

Received 7th February 2019

Accepted 3rd May 2019

DOI: 10.1039/c9ra01012b

rsc.li/rsc-advances
Check for updates

\section{Sulfonic acid functionalized metal-organic framework (S-IRMOF-3): a novel catalyst for sustainable approach towards the synthesis of acrylonitriles $\uparrow$}

\begin{abstract}
Ryhan Abdullah Rather and Zeba N. Siddiqui (D)*
A sulfonic acid functionalized metal-organic framework (S-IRMOF-3) has been synthesized by dropwise addition of chlorosulfonic acid $(0.5 \mathrm{~mL})$ in IRMOF-3 $(1 \mathrm{~g})$ containing $20 \mathrm{~mL}$ of $\mathrm{CHCl}_{3}$ at $0{ }^{\circ} \mathrm{C}$ under simple stirring. The catalyst was applied in Knoevenagel condensation of various aromatic and heteroaromatic aldehydes forming acrylonitrile derivatives. The catalyst was characterized thoroughly by using FT-IR, XRD, ${ }^{13} \mathrm{C}$ MAS NMR, SEM, EDX, elemental mapping, TEM, BET, NH $3-T P D$ and TGA/DTA techniques. The presence of characteristic bands at $1694 \mathrm{~cm}^{-1}, 1254-769 \mathrm{~cm}^{-1}$ and $1033 \mathrm{~cm}^{-1}$ in the FT-IR spectrum, $2 \theta \simeq 6.7^{\circ}$ and $9.8^{\circ}$ in the XRD pattern and $\delta=31.79,39.55,129.61,131.46(4 \mathrm{C}, \mathrm{CH}), 133.54$, 140.07 (2C), 167.71, $171.47 \mathrm{ppm}(2 \mathrm{C}, 2 \mathrm{C}=\mathrm{O})$ in the solid state ${ }^{13} \mathrm{C}$ MAS NMR spectrum confirmed the successful formation of catalyst. This new eco-friendly approach resulted in a significant improvement in the synthetic efficiency (90-96\% yield), high product purity, and minimizing the production of chemical wastes without using highly toxic reagents for the synthesis of acrylonitriles with selectivity for $(Z)$ isomer. Steric interactions seem to have an influence on the control of the $Z$-configurational isomers. By performing DFT calculations, it was found that the (Z)-isomer $3 a$ is stabilized by $1.64 \mathrm{kcal} \mathrm{mol}^{-1}$ more than the $(E)$-isomer. The catalyst could be reused for five consecutive cycles without substantial loss in catalytic activity.
\end{abstract}

\section{Introduction}

Although the story of metal-organic frameworks (MOFs) had already begun earlier in the 20th century, ${ }^{1,2}$ the intensive development of MOF chemistry was initiated in the midnineties. ${ }^{3}$ This new area of research has caught the attention of many academic and industrial researchers leading to a lot of innovations and discoveries that can be traced in the literature over the past two decades. ${ }^{4}$ Several aspects such as the surprisingly intrinsic properties as well as the structural diversity of MOFs afford an almost infinite number of possible structures and make MOFs the subject of extensive research. The MOFs which are synthesized by self-assembly of metal ions or clusters with polytopic organic linkers ${ }^{5}$ have attracted much attention in heterogeneous catalysis due to their intriguing features such as extraordinarily large surface area, well-defined pore structure, easily tailorable chemistry, and high acid-base catalytic activities. ${ }^{6}$ Because of their high intrinsic metal loading, they have been intensively studied as catalysts in

Department of Chemistry, Aligarh Muslim University, Aligarh 202002, Uttar Pradesh, India.E-mail: siddiqui_zeba@yahoo.co.in

$\dagger$ Electronic supplementary information (ESI) available. See DOI: $10.1039 / \mathrm{c} 9 \mathrm{ra} 01012 \mathrm{~b}$ various reactions such as aldol condensation, ${ }^{7}$ Suzuki coupling, ${ }^{8}$ Friedel-Crafts reactions, ${ }^{9}$ Biginelli reaction, ${ }^{10}$ Claisen-Schmidt condensation, ${ }^{11}$ Beckmann rearrangement, ${ }^{12}$ Sonogashira reaction, ${ }^{13}$ polymerization ${ }^{14}$ etc. In recent years there has been remarkable growth in the synthesis of MOFs, largely due to their potential applications in gas storage, separations, catalysis, nonlinear optics, magnetic and electronic materials, and so on. ${ }^{15,16}$ Different heterogeneous MOF-based catalysts have been formulated over the past few decades by introducing different types of catalytic sites into porous MOF matrices. ${ }^{17,18}$ Keeping in view all these eye-catching properties, MOFs could be promising materials for applications in heterogeneous catalysis and can be employed as solid catalysts or catalyst supports for a variety of organic transformations.

Functionalized sulfonic acid has been used to catalyze a variety of reactions.$^{19}$ Integration of acidic functional groups (e.g., $-\mathrm{SO}_{3} \mathrm{H}$ ) on different support materials has produced promising solid acids ${ }^{20}$ which have shown improved reaction properties over conventional homogeneous or heterogeneous catalysts for a wide range of acid-catalyzed reactions, including condensation and addition, ${ }^{21}$ esterification, ${ }^{22}$ rearrangement, ${ }^{23}$ Friedel-Crafts acylation, ${ }^{24}$ alkylation ${ }^{25}$ and conversion of biorenewable molecules. ${ }^{26}$ Taking into account the catalytic performance of sulfonic acid functional groups $\left(-\mathrm{SO}_{3} \mathrm{H}\right)$ in 
organic synthesis, we have tried to incorporate them on MOF surface, with the aim of combining the properties of MOF and $\mathrm{SO}_{3} \mathrm{H}$ groups and thereby increasing the catalytic activity of the resultant catalyst.

Over the past few decades there has been an increasing dominance in the number of biologically active compounds that contain an acrylonitrile moiety. ${ }^{27}$ The reactivity of heteroaryl acetonitriles has been employed for the synthesis of some nitrogen-bridged heterocycles. ${ }^{28}$ Acrylonitrile derivatives are useful intermediates and scaffolds which possess a wide range of favorable biotic assets such as antiproliferative, ${ }^{29}$ antifungal, ${ }^{30}$ antitumor, ${ }^{31}$ antibacterial, ${ }^{32}$ antitubercular, ${ }^{33}$ insecticidal, ${ }^{34}$ hypotensive, ${ }^{35}$ tuberculostatic, ${ }^{36}$ AChE inhibitive $^{37}$ and antiparasitic properties. ${ }^{38}$ It was recently reported that 2-acetyl-3-(6-methoxybenzothiazo)-2-ylaminoacrylonitrile possesses significant anti-proliferative activity and is an effective inducer of programmed cell death in human leukemia cells. ${ }^{39}$ The synthesis of acrylonitrile compounds has previously been achieved by the use of Wittig reactions, ${ }^{40}$ McMurry coupling reactions ${ }^{41}$ and the Heck reaction. ${ }^{42}$ Among different methods, Knoevenagel condensation is a simple and straightforward approach for the synthesis of acrylonitrile derivatives. ${ }^{43}$ This method involves the acid- or base-catalyzed condensation of active methylene moieties with carbonyl compounds. Earlier investigations for this approach required long reaction times, the use of hazardous reagents and tedious workup procedures.

In view of the above considerations and copious biological applications of acrylonitrile derivatives and in continuation of our ongoing research ${ }^{44}$ on supported heterogeneous catalysts, we herein explored the use of a catalyst, sulfonic acid functionalized IRMOF-3 (S-IRMOF-3), for the synthesis of acrylonitrile derivatives using Knoevenagel condensation. The catalyst S-IRMOF-3 proved to be a sustainable alternative having good catalytic activity and recyclability and more importantly enhancing the rate of product formation.

\section{Results and discussion}

The synthesis of S-IRMOF-3 is outlined in Scheme 1.

\section{Catalyst characterization}

The FT-IR spectra of IRMOF-3, S-IRMOF-3 and recycled SIRMOF-3 are shown in Fig. 1. The FT-IR spectrum of IRMOF-3 displayed an absorption band at $2961 \mathrm{~cm}^{-1}$ assigned to $\mathrm{C}-\mathrm{H}$ stretching vibration. The strong peak appearing at $1694 \mathrm{~cm}^{-1}$ was attributed to $\mathrm{C}=\mathrm{O}$ stretching vibration of the carboxylate group of IRMOF-3. ${ }^{45}$ The characteristic peak at $1622 \mathrm{~cm}^{-1}$ corresponded to conjugated $\mathrm{C}=\mathrm{C}$ stretching and the peak at $1388 \mathrm{~cm}^{-1}$ was associated with $\mathrm{O}-\mathrm{H}$ bending deformation in $-\mathrm{COOH} .{ }^{45}$ Peaks in the range of $1254-769 \mathrm{~cm}^{-1}$ were attributed to the in-plane vibration of the BDC group. ${ }^{46 a}$ The two peaks in the range of $769-900 \mathrm{~cm}^{-1}$ were assigned to $=\mathrm{CH}$ aromatic plane bends, which showed that the phenyl ring is 1,4substituted. The symmetric stretching vibration of $\mathrm{Zn}-\mathrm{O}$ appearing at $610 \mathrm{~cm}^{-1}$ is also consistent with the literature. ${ }^{\mathbf{4 6 b}}$ Peaks at 3450 and $3350 \mathrm{~cm}^{-1}$ were attributed to the asymmetric and symmetric stretching absorptions of primary amine group respectively. One of the stretching frequencies of the amine group of the $\mathrm{NH}_{2} \mathrm{H}_{2}$ BDC linker disappeared after formation of the $\mathrm{SO}_{3} \mathrm{H} @ I R M O F-3$ composites, suggested occurrence of the

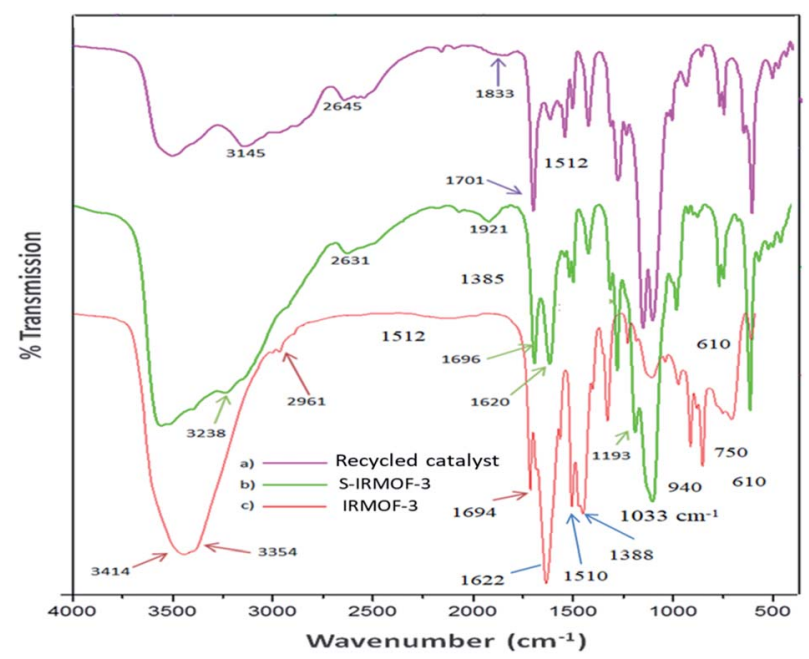

Fig. 1 The infrared spectra of IRMOF-3, S-IRMOF-3 and recycled SIRMOF-3.

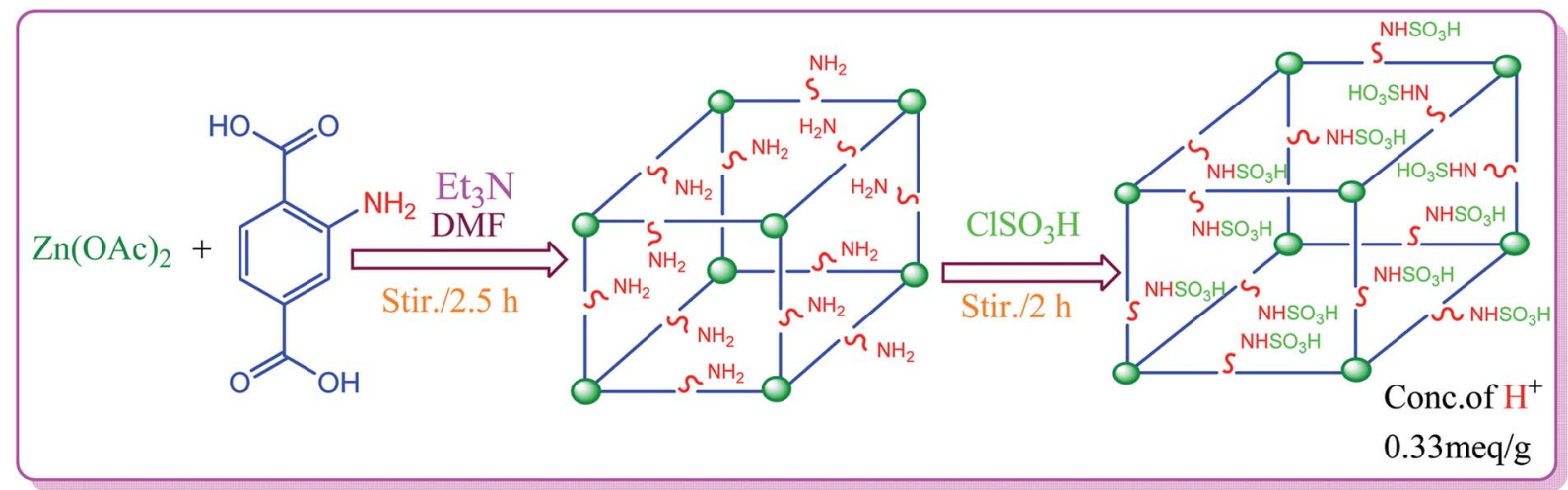

Scheme 1 


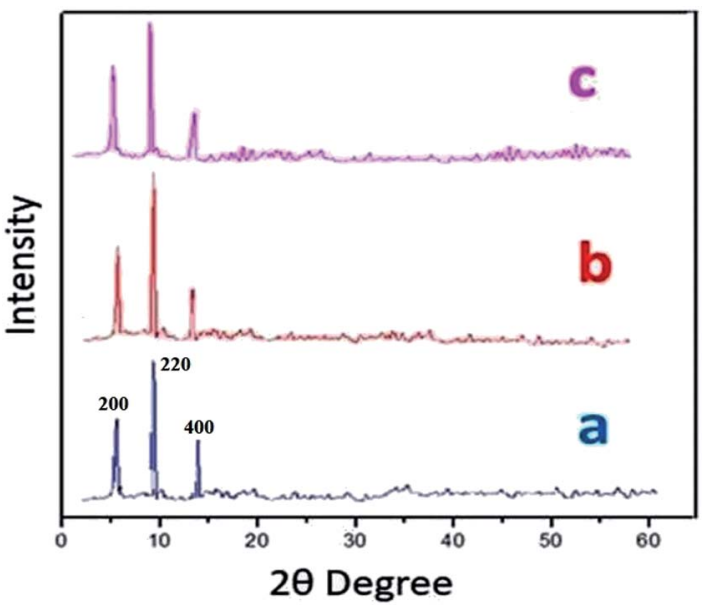

Fig. 2 XRD patterns of (a) IRMOF-3, (b) S-IRMOF-3 and (c) recycled SIRMOF-3.

$\mathrm{NHSO}_{3} \mathrm{H}$ group which was confirmed by the sharp peak appearing at $1193 \mathrm{~cm}^{-1}$. Furthermore the band at $1033 \mathrm{~cm}^{-1}$ corresponded to the $\mathrm{O}=\mathrm{S}=\mathrm{O}$ stretching in $\mathrm{SO}_{3} \mathrm{H}$ group.

Powder X-ray diffraction (PXRD) data were obtained in order to evaluate S-IRMOF-3 structural stability/homogeneity. Fig. 2 compares PXRD patterns of neat IRMOF-3 and S-IRMOF-3. For the neat IRMOF-3 specimen, the characteristic peaks at $2 \theta \simeq$ $6.7^{\circ}, 9.8^{\circ}$ and $13.9^{\circ}$ which corresponded to (200), (220) and (400) planes respectively confirmed the successful synthesis of IRMOF-3 (Fig. 2a). ${ }^{47}$ For S-IRMOF-3, the same characteristic diffraction peaks at $2 \theta \simeq 6.7^{\circ}, 9.8^{\circ}$ and $13.8^{\circ}$ were observed with no other notable changes in the peak patterns and indicated that both IRMOF-3 and S-IRMOF-3 had the same structure phase.

The solid state ${ }^{13} \mathrm{C}$ MAS nuclear magnetic resonance $\left({ }^{13} \mathrm{C}\right.$ MAS NMR) spectrum of S-IRMOF-3 is depicted in Fig. 3. The spectrum indicated eight peaks which corresponded to $\delta=$ $31.79,39.55,129.61,131.46(4 \mathrm{C}, \mathrm{CH}), \delta=133.54,140.07$ (2C), $\delta=167.71,171.47 \mathrm{ppm}(2 \mathrm{C}, 2 \mathrm{C}=\mathrm{O})$ supporting the structure of IRMOF-3. The signals at $\delta=31.79$ and $39.55 \mathrm{ppm}$ were due to trapped DMF solvent molecule in S-IRMOF-3. ${ }^{48}$

The SEM images of IRMOF-3 and the catalyst S-IRMOF- 3 at different magnifications are shown in Fig. 4. There were slight changes in the surface morphology of S-IRMOF-3 (Fig. 4b) as compared to IRMOF-3 (Fig. 4a) due to surface $\mathrm{SO}_{3} \mathrm{H}$ groups. The EDX analysis (Fig. 5a) showed the presence of C, O, S, Zn and $\mathrm{N}$ elements, while the elemental mapping of C, O, N, S and Zn elements of S-IRMOF-3 (Fig. 5b) clearly demonstrates that $\mathrm{SO}_{3} \mathrm{H}$ groups were well distributed into the surfaces of $\mathrm{S}$ IRMOF-3.

In order to further observe the morphology of S-IRMOF-3, TEM images were obtained. It can be seen from the contrast TEM image of S-IRMOF-3 (Fig. 6A) that it presents a cube like

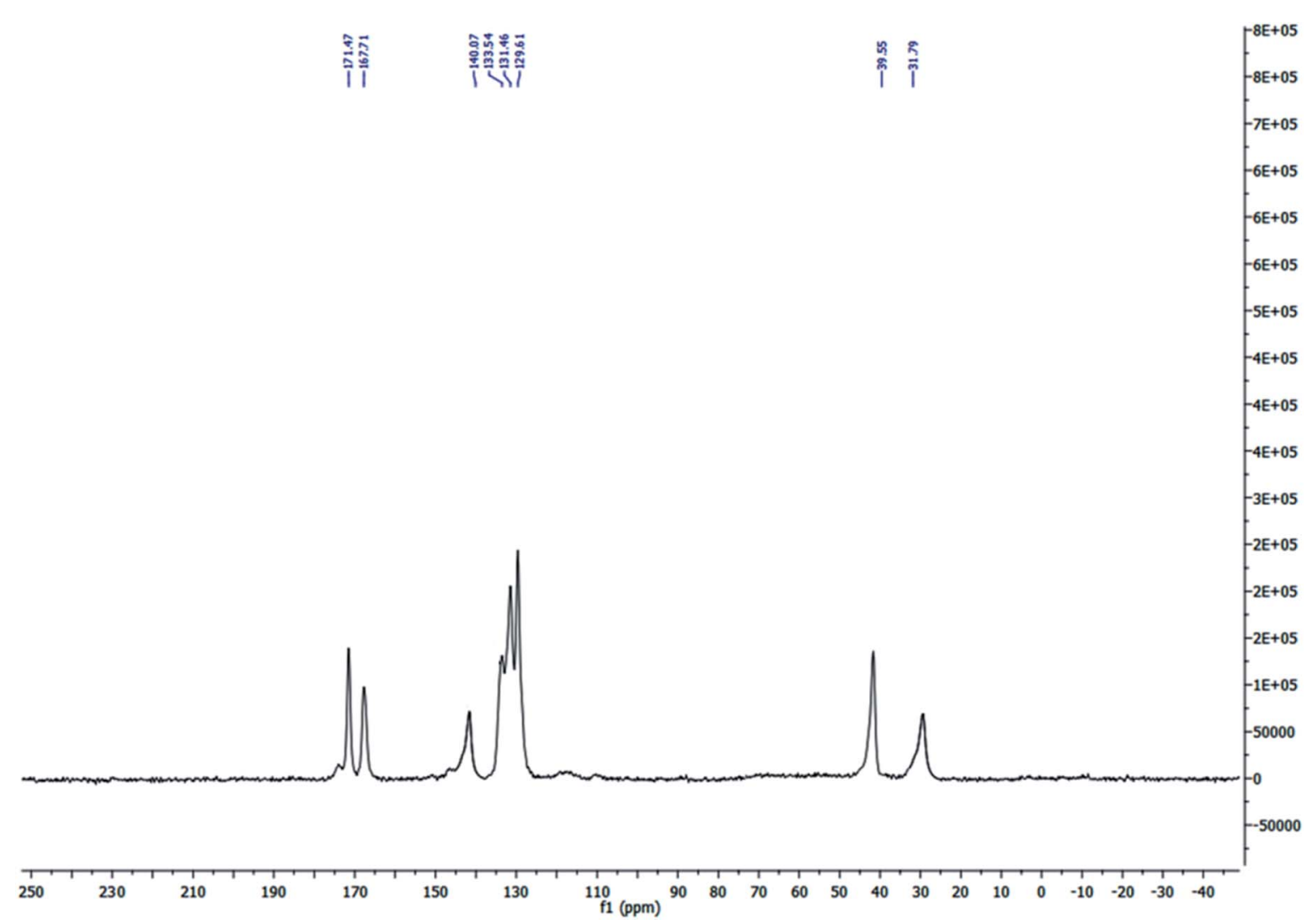

Fig. 3 Solid state ${ }^{13} \mathrm{C}$ MAS NMR spectrum of S-IRMOF-3. 


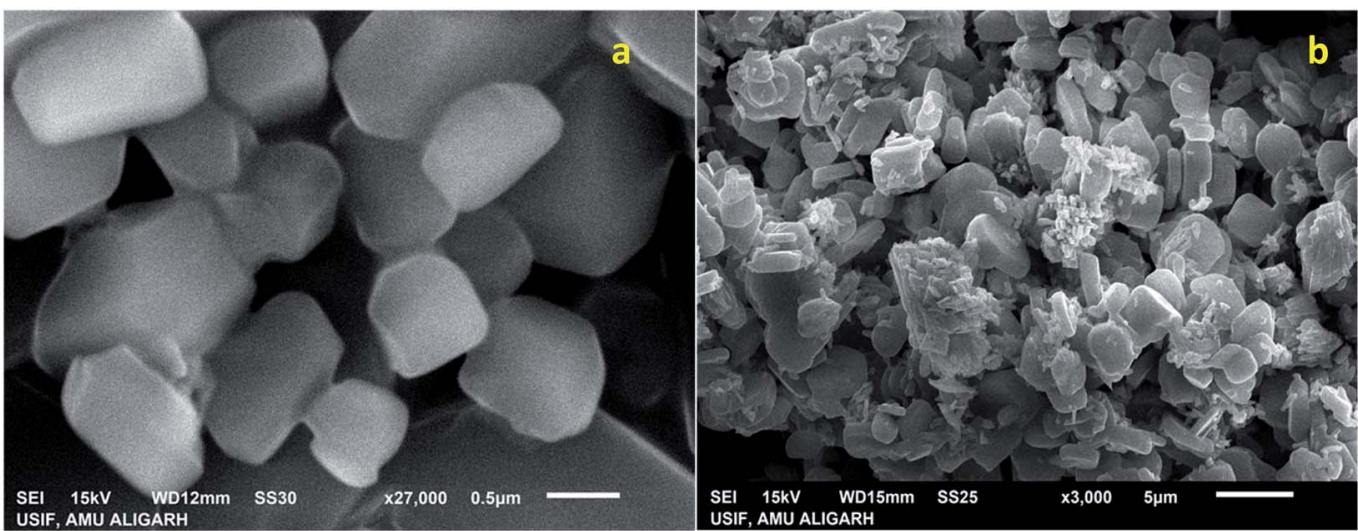

Fig. 4 SEM images of (a) IRMOF-3 and (b) the synthesized catalyst (S-IRMOF-3) at different magnifications.

structure that corresponds to the fact that IRMOF-3 was not altered during functionalization of IRMOF-3. The dark shades that are observed in the TEM images of S-IRMOF-3 are attributed to sulfonic acid system homogeneously dispersed on the surfaces of IRMOF- 3 composite. There is no further change in the TEM image of recycled S-IRMOF-3 (Fig. 6B).
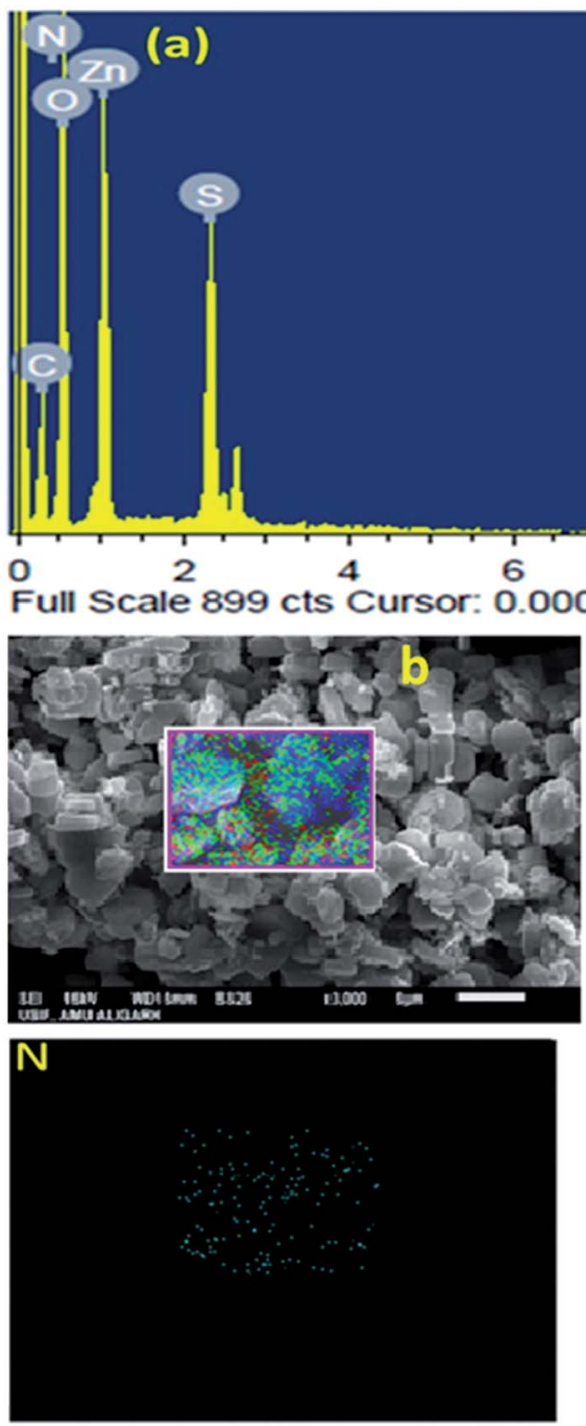

\begin{tabular}{|lrr|}
\hline Element & Weight\% & Atomic\% \\
C K & 25.79 & 34.78 \\
N K & 2.89 & 3.35 \\
O K & 55.24 & 55.93 \\
S K & 8.45 & 2.09 \\
Zn K & 7.63 & 3.85 \\
Totals & 100.00 & \\
\hline
\end{tabular}

14
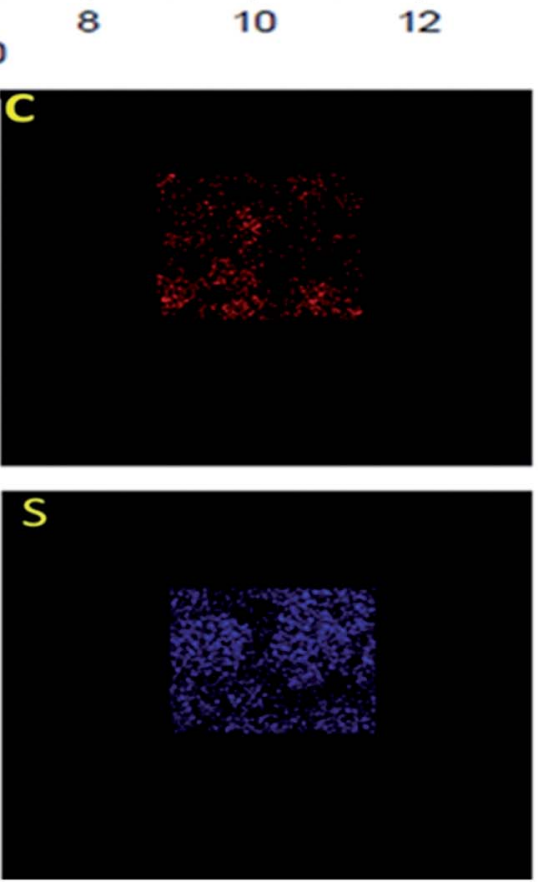
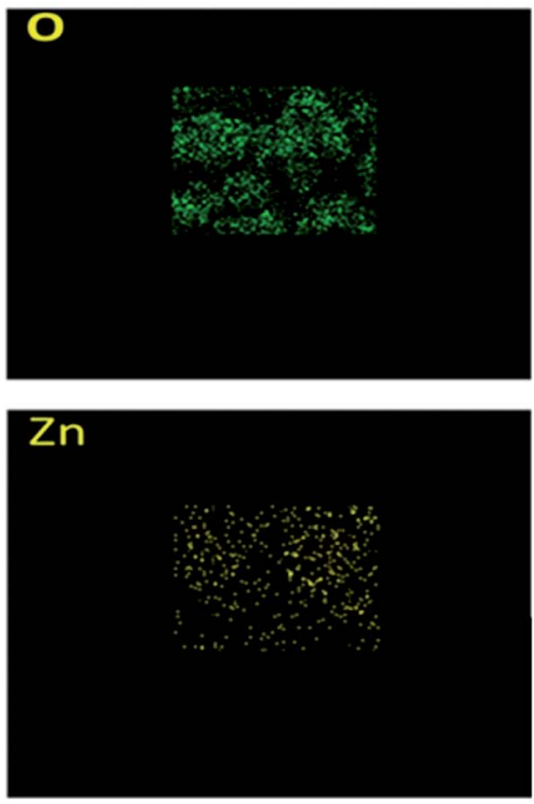

Fig. 5 (a) EDX analysis of S-IRMOF-3. (b) Elemental mapping of S-IRMOF-3. 


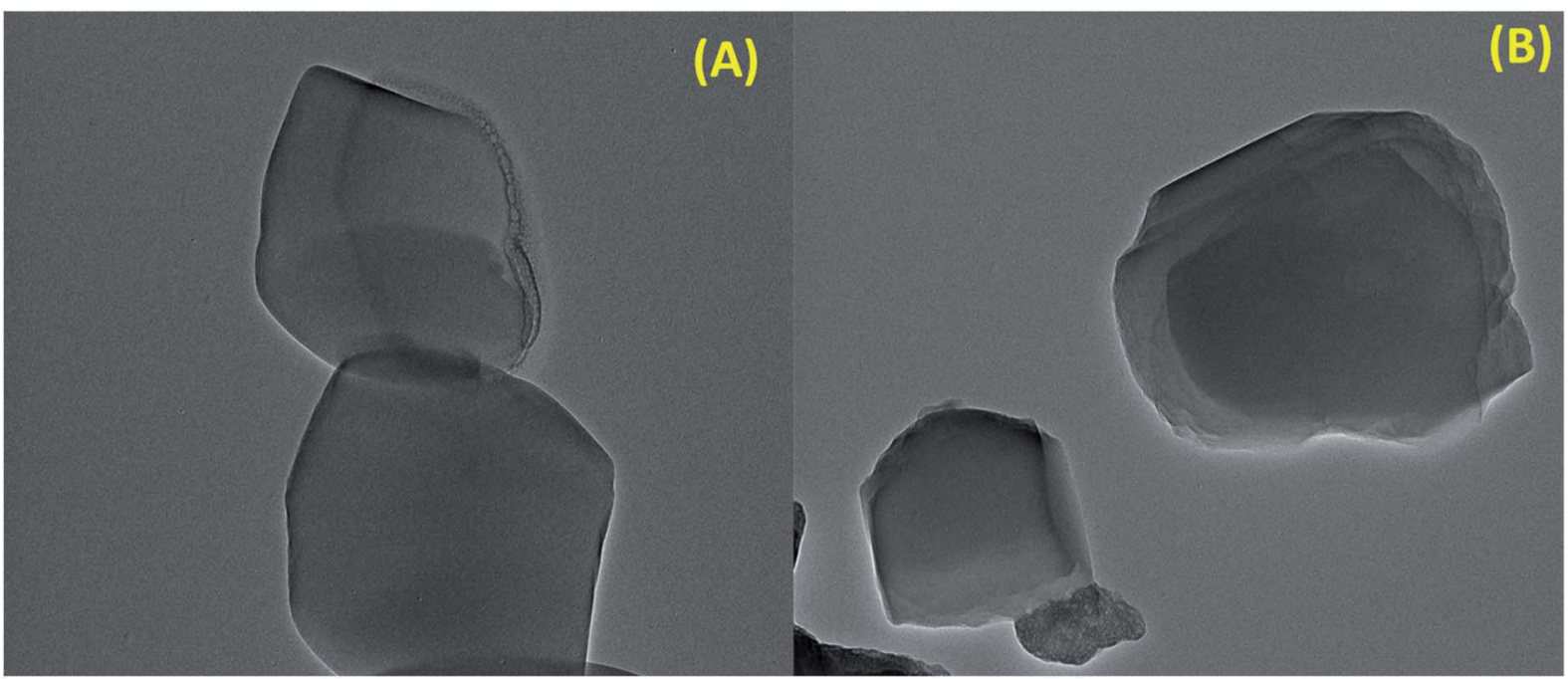

Fig. 6 TEM images of fresh catalyst (A) and recycled catalyst (B).

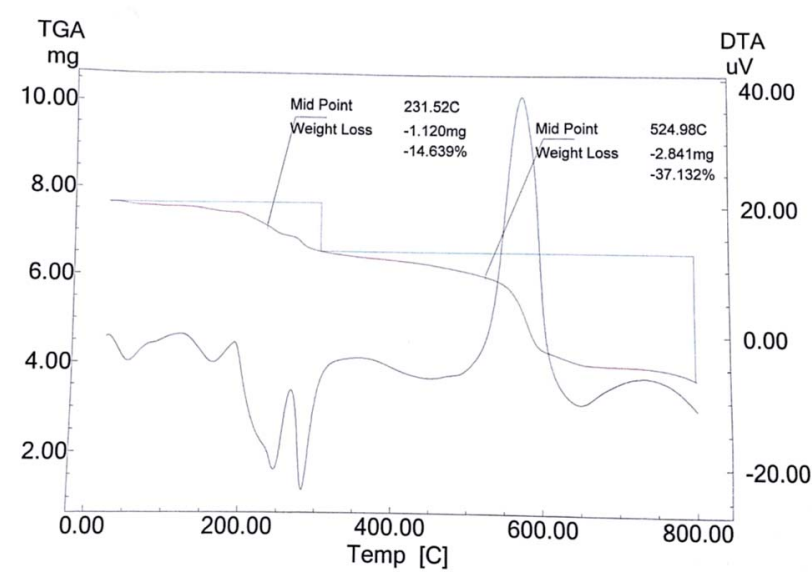

Fig. 7 TG/DT analysis of the catalyst.

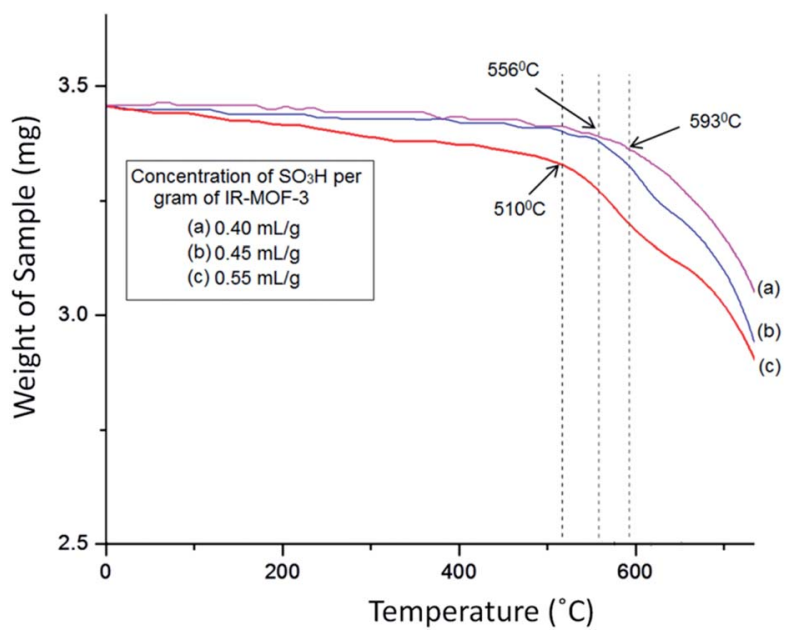

Fig. 8 Effect of $\mathrm{SO}_{3} \mathrm{H}$ content on thermal stability of catalyst.
The TG curve (Fig. 7) of catalyst S-IRMOF-3 recorded a first weight loss at $231{ }^{\circ} \mathrm{C}$ caused by the removal of DMF and a second weight loss at $524{ }^{\circ} \mathrm{C}$ due to removal of $\mathrm{SO}_{3} \mathrm{H}$ group. ${ }^{49}$ S-IRMOF-3 with different weight percentages showed high thermal stability up to $550^{\circ} \mathrm{C}$ while that of pure IRMOF-3 was up to $440{ }^{\circ} \mathrm{C}^{50}$ The catalyst then did not show any further weight loss up to $550^{\circ} \mathrm{C}$. This confirmed that the catalyst was stable up to this temperature as shown also by DT analysis. In addition, the DT analysis curve showed a sharp peak at around $590{ }^{\circ} \mathrm{C}$ which confirmed the exothermic nature of the catalyst (Fig. 7). Thus, TG and DT analyses showed that the catalyst can tolerate a wide range of temperature. Furthermore, the thermal stability of the catalyst was also confirmed by varying the $\mathrm{SO}_{3} \mathrm{H}$ content. It was observed that thermal stability of the catalyst was reduced on increasing the concentration of $\mathrm{SO}_{3} \mathrm{H}$ from $0.40 \mathrm{~mL} \mathrm{~g}^{-1}$ to $055 \mathrm{~mL} \mathrm{~g}^{-1}$ as shown in Fig. 8. At the same time, the activity of the catalyst was enhanced due to an increase in acidity of the catalyst (Table $\mathrm{S} 1 \dagger$ ).

The specific surface area and pore volume of IRMOF-3 and S-IRMOF-3 were calculated using the Brunauer-EmmettTeller (BET) method. The surface area of IRMOF-3 was reduced from $1342 \mathrm{~m}^{2} \mathrm{~g}^{-1}$ to $1299 \mathrm{~m}^{2} \mathrm{~g}^{-1}$ (Fig. 9a and b) and pore volume reduced from $0.061 \mathrm{~cm}^{3} \mathrm{~g}^{-1}$ to $0.050 \mathrm{~cm}^{3} \mathrm{~g}^{-1}$ (Fig. 9c and d). The reduction of surface area and pore volume may be due to sulfonic acid functionalization of IRMOF-3.

The acidic sites of IRMOF-3 and S-IRMOF-3 were compared using $\mathrm{NH}_{3}$-TPD measurement (Fig. 10). The $\mathrm{NH}_{3}$ desorption peaks for IRMOF-3 indicated different adsorption sites for the ammonia species with different thermal stabilities. The lowtemperature $\left(188^{\circ} \mathrm{C}\right)$ desorption peak was attributed to ammonium species adsorbed at Lewis acid sites, while the hightemperature $\left(336{ }^{\circ} \mathrm{C}\right)$ desorption peak was assigned to high thermal adsorption of ammonium species on Brønsted acid sites. $^{51}$ It was observed that after the sulfonic acid 

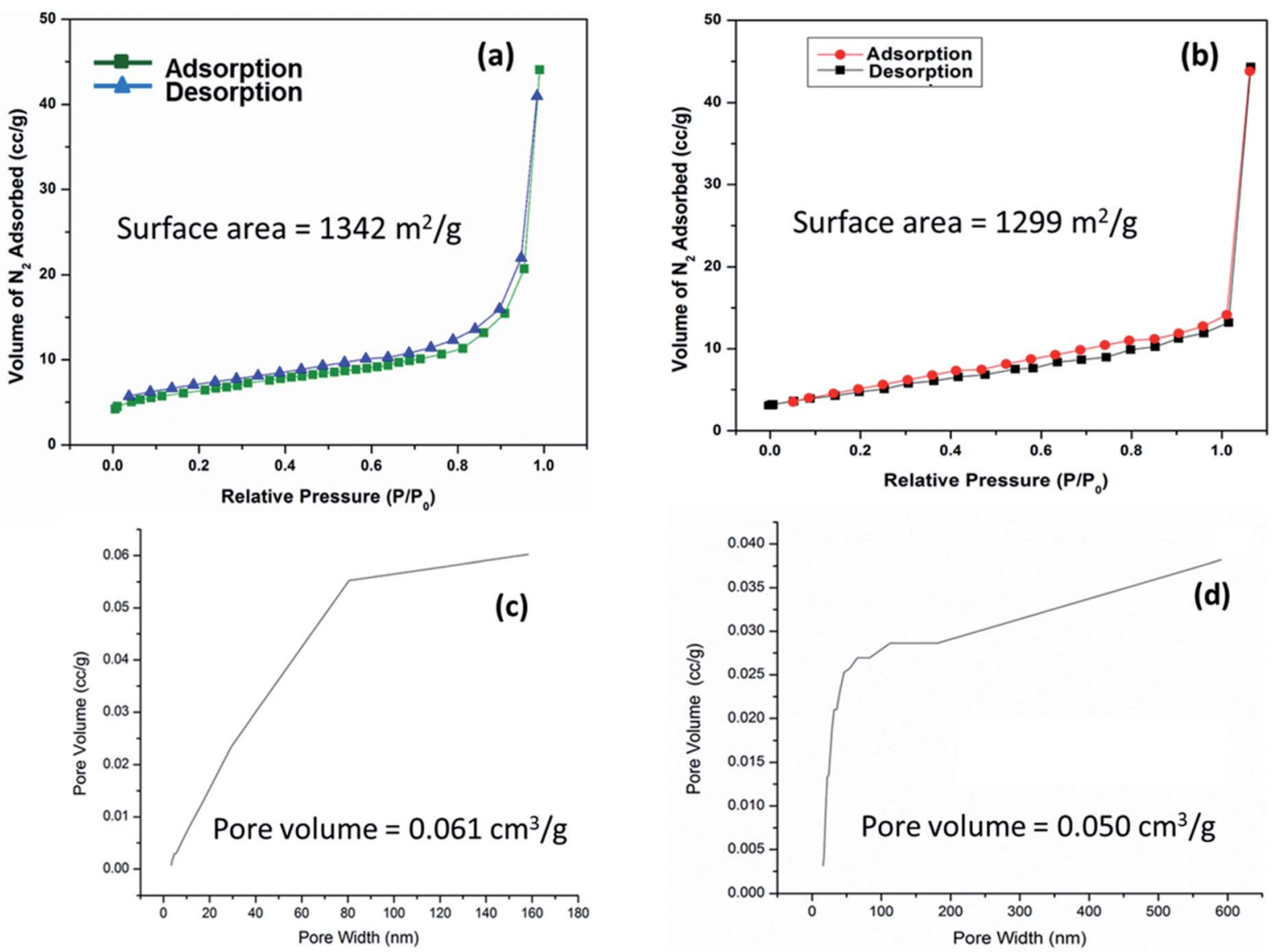

Fig. $9 \mathrm{~N}_{2}$ adsorption isotherms of (a) IRMOF-3 and (b) S-IRMOF-3. PSD of (c) IRMOF-3 and (d) S-IRMOF-3.

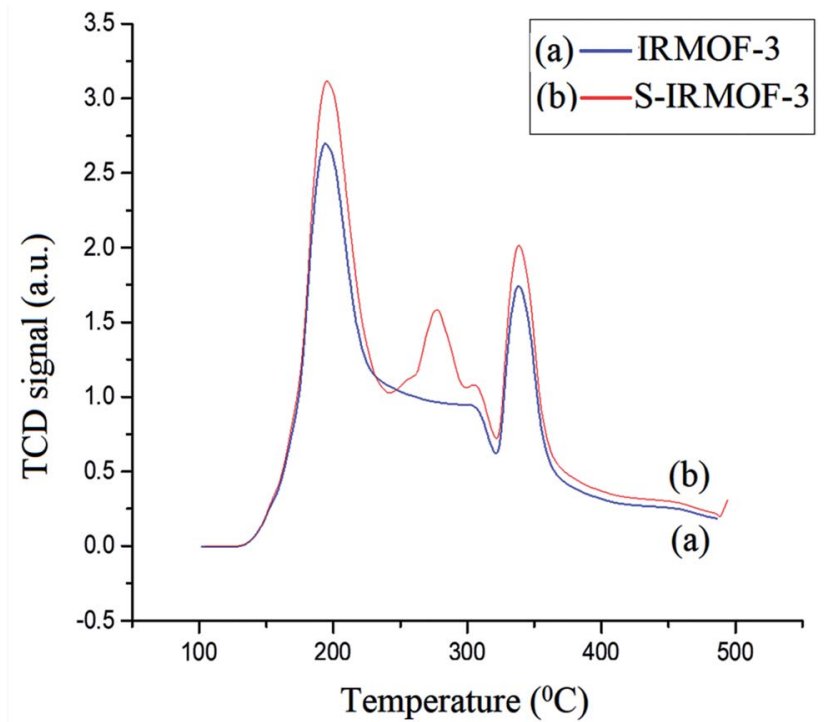

Fig. $10 \mathrm{NH}_{3}-$ TPD curves of (a) IRMOF-3 and (b) S-IRMOF-3.

functionalization, an additional peak at $281{ }^{\circ} \mathrm{C}$ appeared in $\mathrm{NH}_{3}$-TPD measurements of S-IRMOF-3 which may be due to $\mathrm{SO}_{3} \mathrm{H}$ groups on the IRMOF-3 framework. ${ }^{52}$
Table 1 Effect of different catalysts for the synthesis of $3 a^{a}$

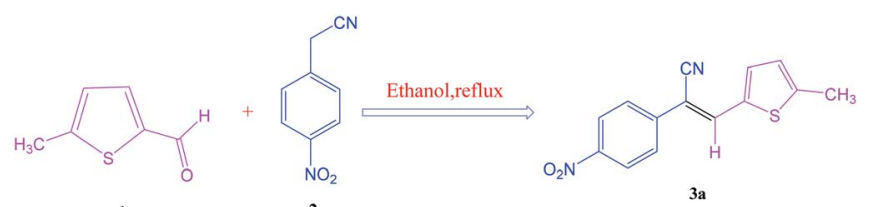

\begin{tabular}{llll}
\hline Entry & Catalyst & Time $^{b}$ & Yield $^{c}(\%)$ \\
\hline 1 & - & $12 \mathrm{~h}$ & Traces \\
2 & PTSA & $5.5 \mathrm{~h}$ & 58 \\
3 & Acetic acid & $4.6 \mathrm{~h}$ & 50 \\
4 & Chlorosulfonic acid & $3.5 \mathrm{~h}$ & 62 \\
5 & Piperidine & $4.5 \mathrm{~h}$ & 60 (impure) \\
6 & Sodium methoxide & $8 \mathrm{~h}$ & 56 (impure) \\
7 & Cl-SiO & 88 \\
8 & MOF-5(T) & $2 \mathrm{~h}$ & 78 \\
9 & IRMOF-3 & $1.5 \mathrm{~h}$ & 80 \\
10 & S-IRMOF-3 & $1.5 \mathrm{~h}$ & 96
\end{tabular}

${ }^{a}$ Reaction conditions: 5-methyl-2-thiophenecarboxaldehyde (1a, 1 $\mathrm{mmol}), \quad p$-nitrophenylacetonitrile $(1 \mathrm{mmol})$, different catalysts $(2.5 \mathrm{~mol} \%)$, EtOH $(10 \mathrm{~mL}) .{ }^{b}$ Reaction progress monitored by TLC. ${ }^{c}$ Isolated yield of products. 
Table 2 Effect of various solvents on the model reaction ${ }^{a}$

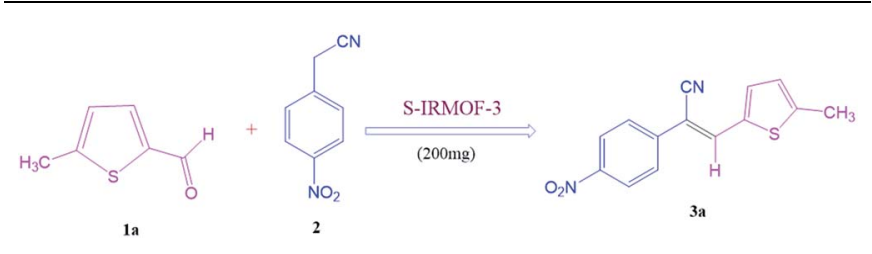

\begin{tabular}{llll}
\hline Entry & Solvent & Time $^{b}$ & Yield $^{c}(\%)$ \\
\hline 1 & Solvent free & & \\
2 & Ethanol $^{d}$ & - & Traces \\
3 & Methanol & $2 \mathrm{~h}$ & 96 \\
4 & Acetonitrile & $3 \mathrm{~h}$ & 74 \\
5 & Water & $6 \mathrm{~h}$ & 68 \\
6 & Chloroform & $4 \mathrm{~h}$ & 60 \\
7 & Isopropanol & $5 \mathrm{~h}$ & 58 \\
8 & DMF & $6 \mathrm{~h}$ & 55 \\
9 & Acetic acid & $7 \mathrm{~h}$ & 52 \\
10 & PEG-200 & $8 \mathrm{~h}$ & 70 \\
11 & PEG-400 & $7 \mathrm{~h}$ & 48 \\
12 & PEG-600 & $7 \mathrm{~h}$ & 46 \\
\end{tabular}

${ }^{a}$ Reaction conditions: 5-methyl-2-thiophenecarboxaldehyde (1a, 1 mmol), $p$-nitrophenylacetonitrile $(1 \mathrm{mmol})$, catalyst $(2.5 \mathrm{~mol} \%)$, different solvents $(10 \mathrm{~mL}) .{ }^{b}$ Reaction progress monitored by TLC. ${ }^{c}$ Isolated yield of products. ${ }^{d}$ Solvent-free by grinding method.

Table 3 Effect of catalyst amount on the synthesis of $3 a^{a}$

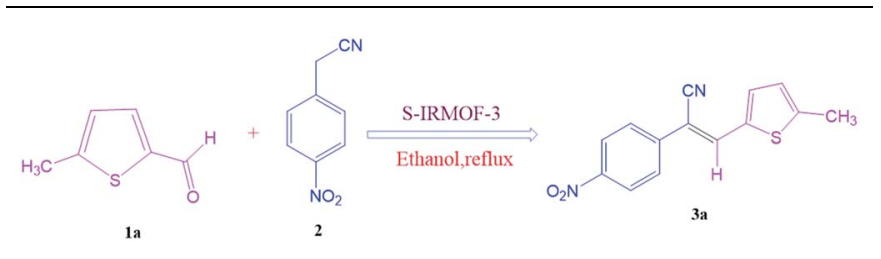

\begin{tabular}{llll}
\hline Entry & $\begin{array}{l}\text { Catalyst } \\
(\mathrm{mg})\end{array}$ & Time $^{b}$ & Yield $^{c}(\%)$ \\
\hline 1 & 50 & $1.5 \mathrm{~h}$ & 80 \\
2 & 100 & $1.0 \mathrm{~h}$ & 88 \\
3 & 150 & $50 \mathrm{~min}$ & 92 \\
4 & 200 & $30 \mathrm{~min}$ & 96 \\
5 & 250 & $30 \mathrm{~min}$ & 96
\end{tabular}

${ }^{a}$ Reaction conditions: 5-methyl-2-thiophenecarboxaldehyde (1a, 1 mmol), $p$-nitrophenylacetonitrile $(1 \mathrm{mmol})$, EtOH solvent. ${ }^{b}$ Reaction progress monitored by TLC. ${ }^{c}$ Isolated yield of products.

\section{Optimization of reaction conditions}

To investigate the viability of our protocol for the synthesis of various acrylonitrile derivatives, a sequence of experiments were carried out using 3-methyl-2-thiophenecarboxaldehyde and $p$-nitrophenylacetonitrile as model substrates. Several controlled experiments were performed, first without any catalyst and subsequently using PTSA, acetic acid, and chlorosulfonic acid as catalysts in ethanol at ambient temperature, the results being found to be unsatisfactory (Table 1, entries 1 to 4). Use of basic catalyst such as piperidine and NaOMe also did not work (Table 1, entries 5 and 6). Application of MOFs (including IRMOF-3), however, showed encouraging results (Table 1, entries 8 and 9). Finally when S-IRMOF-3 was used (Table 1, entry 10) the reaction proceeded smoothly affording excellent yield of the product. The reaction conditions were further optimized by examining the solvent effect on the reaction. The reaction was first tested under solvent-free conditions by the grinding method; however only traces of product were obtained (Table 2, entry 1 ). When the reaction was carried out in different protic and aprotic solvents, the best results in terms of yield $(96 \%)$ and time period (30 min) were obtained with ethanol (Table 2, entry 2). In order to find the optimized amount of the catalyst, the reaction was carried out by varying the amount of the catalyst in the model reaction (Table 3). It was found that the yield of the acrylonitrile derivatives increased linearly with an increase in the amount of catalyst from 50 to $200 \mathrm{mg}$ (Table 3, entries 1-4). Further increase in the amount of catalyst did not have any profound effect on the reaction (Table 3 , entry 5). Therefore, $200 \mathrm{mg}$ of S-IRMOF- 3 was used for the synthesis of acrylonitriles.

\section{Catalytic reaction}

After optimization of reaction conditions, the substrate scope of the S-IRMOF-3-catalyzed synthesis of acrylonitrile derivatives (Scheme 2) was examined (Table 4). The results showed that the reaction proceeded efficiently with both aromatic as well as hetero-aromatic aldehydes bearing both electron-releasing and electron-withdrawing groups.

\section{Reaction mechanism}

A plausible mechanism for the synthesis of acrylonitrile derivative 3a is outlined in Scheme 3. Among the two possible isomers $(E$ and $Z$ ), the $(Z)$-isomer was obtained as the sole product (Scheme 3 ). This $Z$-selectivity can be inferred as a way to<smiles>CCCC(=O)N[R16](=O)[O-]</smiles>

Scheme 2 General scheme for the formation of acrylonitrile derivatives. 
Table 4 Scope of different substrates for the synthesis of acrylonitrile derivatives ${ }^{a}$

1<smiles>Cc1ccc(C=O)s1</smiles>

$1 a$<smiles>O=Cc1cccs1</smiles>

3<smiles>O=Cc1coc2ccccc2c1=O</smiles><smiles>ClC/C=C/c1ccccc1</smiles><smiles>O=Cc1cccc(C=O)c1</smiles><smiles>Cc1nn(-c2ccccc2)c(Cl)c1C=O</smiles>
$1 f$<smiles>O=Cc1cccnc1</smiles><smiles>Cc1ccc(/C=C(\C#N)c2ccc([N+](=O)[O-])cc2)s1</smiles>

$3 a$<smiles>N#C/C(=C\c1cccs1)c1ccc([N+](=O)[O-])cc1</smiles>

$3 b$<smiles>[2H]c1oc2ccccc2c(=O)c1/C=C(\C#N)c1ccc([N+](=O)[O-])cc1</smiles>

$3 d$<smiles>N#C/C(=C\c1cccc(C=O)c1)c1ccc([N+](=O)[O-])cc1</smiles>

$3 e$<smiles>CC1=NN(c2ccccc2)C(Cl)C1/C=C/c1ccc([N+](=O)[O-])cc1</smiles>

$3 f$<smiles>N#C/C(=C\c1cccnc1)c1ccc([N+](=O)[O-])cc1</smiles>

40

92

90 
Table 4 (Contd.)

Entry Substrate (1a-o)<smiles>O=CCc1ccccc1</smiles>

9

$1 \mathrm{i}$

10<smiles>O=Cc1ccc(O)cc1</smiles>

11

12<smiles>O=Cc1ccc([N+](=O)[O-])cc1</smiles>

$1 \mathrm{j}$<smiles>O=Cc1ccc(Cl)cc1</smiles><smiles>O=Cc1ccc(F)cc1</smiles>

13

14<smiles>O=Cc1cccc(Cl)c1</smiles>

$$
1 \mathrm{~m}
$$<smiles>O=Cc1cccc(Br)c1</smiles>

1n
Product<smiles>N#C/C(=C\Cc1ccccc1)c1ccc([N+](=O)[O-])cc1</smiles>

$3 \mathrm{~h}$<smiles>N#C/C(=C\c1ccc([N+](=O)[O-])cc1)c1ccc([N+](=O)[O-])cc1</smiles>

$3 i$<smiles>N#C/C(=C\c1ccc(O)cc1)c1ccc([N+](=O)[O-])cc1</smiles>

3j<smiles>N#C/C(=C\c1ccc(Cl)cc1)c1ccc([N+](=O)[O-])cc1</smiles>

$3 k$<smiles>N#C/C(=C\c1ccc(F)cc1)c1ccc([N+](=O)[O-])cc1</smiles>

31<smiles>N#C/C(=C\c1cccc(Cl)c1)c1ccc([N+](=O)[O-])cc1</smiles>

$3 m$<smiles>N#C/C(=C\c1cccc(Br)c1)c1ccc([N+](=O)[O-])cc1</smiles>

$3 n$
Time $^{b}$ (min)

Yield $^{c}(\%)$

30

96

96

30

96 
Table 4 (Contd.)

\begin{tabular}{llrl}
\hline Entry & Substrate $(\mathbf{1} \mathbf{a}-\mathbf{o})$ & Product & Time $^{b}\left(\mathrm{~min}^{2}\right)$ \\
\hline
\end{tabular}

15<smiles>O=Cc1cccc([N+](=O)[O-])c1</smiles>

10<smiles>N#C/C(=C\c1cccc([N+](=O)[O-])c1)c1ccc([N+](=O)[O-])cc1</smiles>

30

${ }^{a}$ Reaction progress monitored by TLC. ${ }^{b}$ Isolated yield. ${ }^{c}$ Compounds characterized by their melting points.

minimize steric interactions between the approaching nucleophile (imide form of $p$-nitrophenylacetonitrile), the bulky aryl substituent and catalyst-bound electron-deficient carbonyl carbon. It favors back-side attack of the nucleophile in such a way that the phenyl ring of the approaching nucleophile is pushed away, thus facilitating the formation of the $(Z)$-isomer. Steric interactions seem to have an influence on the control of the $Z$-configurational isomers. This is further supported by DFT calculations.

\section{Catalyst recycling}

The reusability of the S-IRMOF-3 catalyst was also examined in a model reaction. The catalyst was reused five times and the results show that the catalyst can be reused without a significant drop in product yield (Table 5). The reusability of the catalyst reduces the cost of the reaction. After the first fresh run with $96 \%$ yield (Table 5 , entry 1 ), the catalyst was removed by filtration. The recovered catalyst was dried under vacuum at $120{ }^{\circ} \mathrm{C}$ for $10 \mathrm{~h}$ and tested for five more reaction cycles. Recycling and reuse of the catalyst showed minimal decreases in product

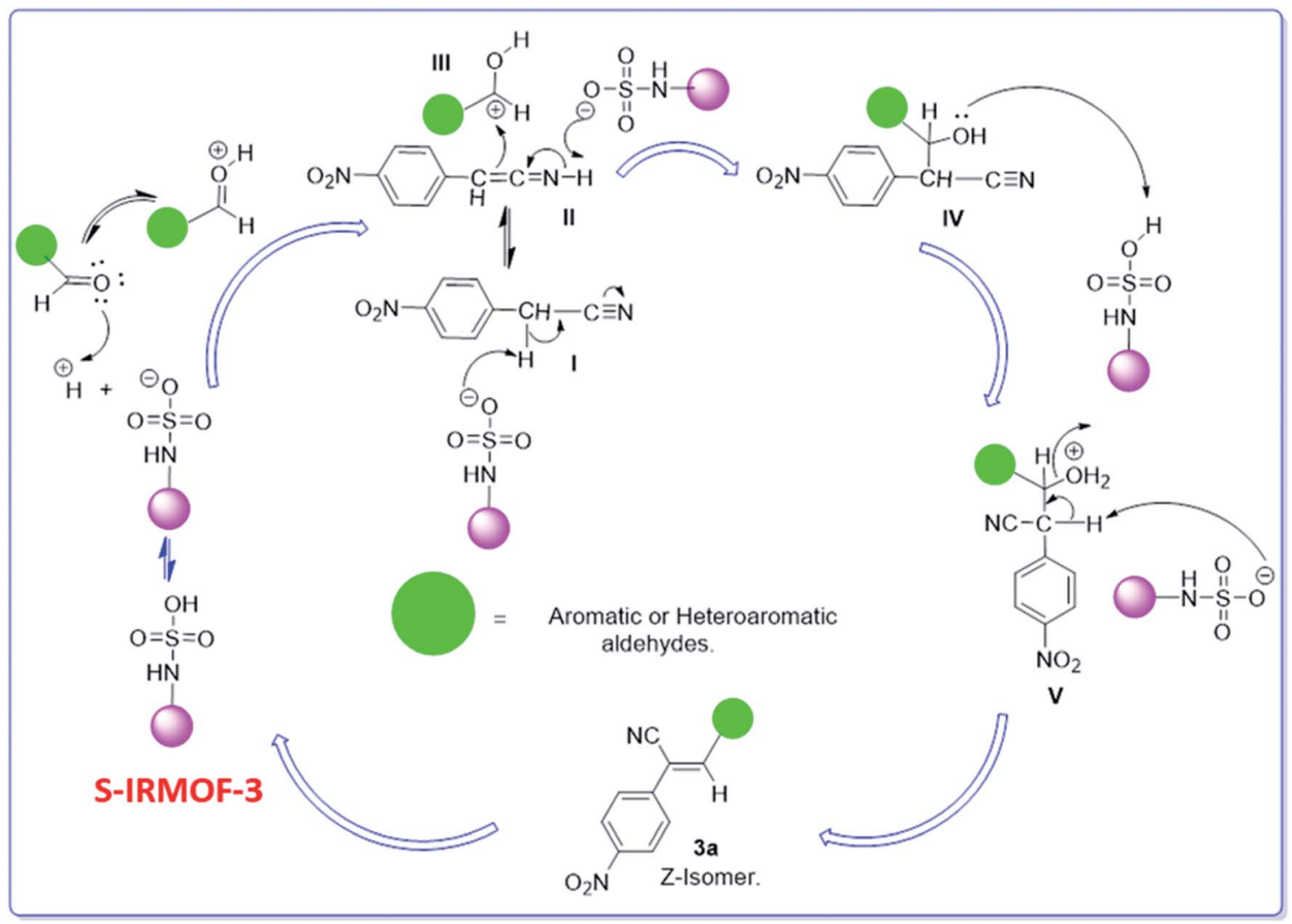

Scheme 3 Proposed reaction mechanism. 
Table 5 Reusability of the S-IRMOF-3 catalyst in the synthesis of compound $3 a$
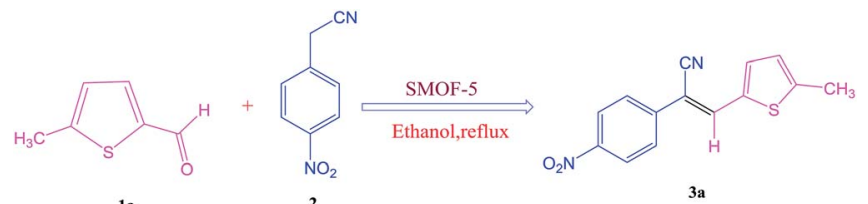

$3 \mathbf{a}$

\begin{tabular}{lll}
\hline Entry & Reaction cycle & Isolated yield (\%) \\
\hline 1 & 1st cycle (fresh run) & 96 \\
2 & 2nd cycle & 94 \\
3 & 3rd cycle & 93 \\
4 & 4th cycle & 91 \\
5 & 5th cycle & 90 \\
6 & 6th cycle & 90
\end{tabular}

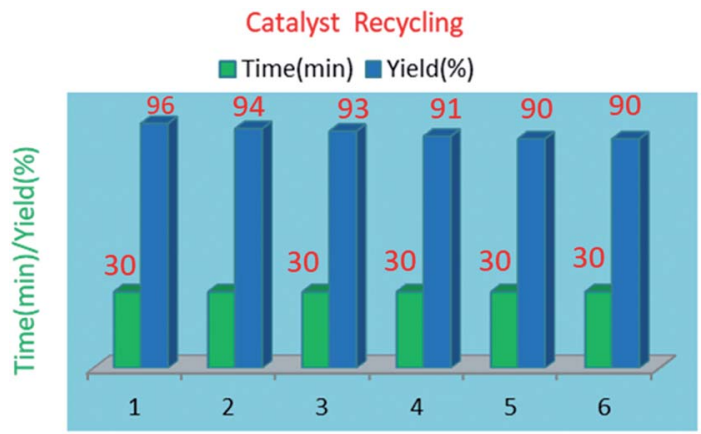

No. of Recycles

Fig. 11 Recycling data of S-IRMOF-3 catalyst.

yields. The product 3a was obtained in 94\%, 93\%, 91\%, 91\% and $90 \%$ yields after successive cycles (Table 5, entries 2-6), thus proving the catalyst's reusability (Fig. 11).

\section{Results of DFT calculations}

DFT calculations were performed on two isomers ( $Z$ and $E$ ) of compound 3a using Gaussian 09 software. ${ }^{53}$ Optimized geometry and IR frequencies of these two isomers were obtained at
B3LYP/6-31G(d,p) level of theory. Optimized geometries of $(Z)$ and $(E)$-isomer are shown in Fig. 12. The minimum molecular energies of $(Z)$ - and $(E)$-isomer were found to be -751470.2065 and $-751468.5656 \mathrm{kcal} \mathrm{mol}^{-1}$ respectively. It was found that the $(Z)$-isomer was stabilized by $1.64 \mathrm{kcal} \mathrm{mol}^{-1}$ more than the $(E)$ isomer. The dipole moment value for the $(Z)$-isomer was estimated to be $7.86 \mathrm{D}$ and the dipole moment vector pointed towards the five-membered ring. The simulated IR spectrum (scaled by uniform scaling factor of 0.961) along with some assignments for the $(Z)$-isomer are shown in Fig. 13. The dominant line at $1363 \mathrm{~cm}^{-1}$ corresponded to the stretching frequency of the nitro group. The $1000-1500 \mathrm{~cm}^{-1}$ region represented the combined skeletal vibrations of the molecule, and the lines at $1604 \mathrm{~cm}^{-1}$ and $1615 \mathrm{~cm}^{-1}$ were dominated by the $\mathrm{C}=\mathrm{C}$ stretching vibration. The $\mathrm{CN}$ stretching vibrational mode was observed at $2312 \mathrm{~cm}^{-1}$. The results were nearly in accordance with the experimentally obtained IR spectrum of the molecule. Spatial plots of HOMO and LUMO along with corresponding energy values and HOMO-LUMO gap are illustrated in Fig. 14. The figure depicts localized HOMO and LUMO over the whole molecule. HOMO-LUMO transition showed the charge delocalization within the molecule.

\section{Conclusion}

In summary the present work reports a new, simple, convenient and eco-friendly functionalized MOF-assisted synthesis of (Z)acrylonitrile derivatives. The products were obtained in excellent yield (90-96\%) with high purity. The prominent features of this procedure are mild reaction conditions, operational simplicity, enhanced reaction rates, cleaner reaction profiles and simple experimental and product separation procedures, which make this method attractive. Furthermore, these features will enable this method to find extensive applications in the field of organic synthesis.

\section{Experimental section}

\section{Synthesis of IRMOF-3}

IRMOF-3 was synthesized according to a reported procedure, ${ }^{54}$ with slight modifications. Aminoterephthalic acid (2 g) and trimethylamine $(4.5 \mathrm{~mL})$ were dissolved in $100 \mathrm{~mL}$ of DMF to which was added $\mathrm{Zn}(\mathrm{OAc})_{2} \cdot 2 \mathrm{H}_{2} \mathrm{O}(6 \mathrm{~g})$ dissolved in $150 \mathrm{~mL}$ of DMF. The reaction mixture was stirred for $2.5 \mathrm{~h}$. The precipitate

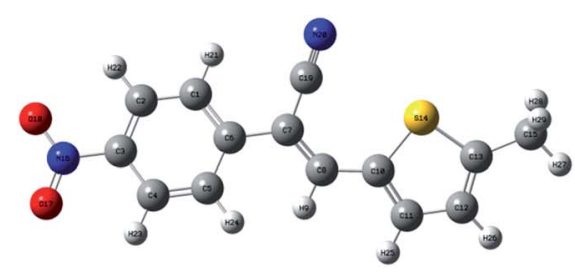

(a) Z- isomer

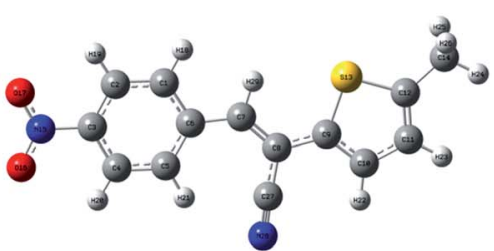

(b) E- isomer

Fig. 12 Ground state optimized structures of the (a) (Z)-isomer and (b) (E)-isomer of compound 3a. 


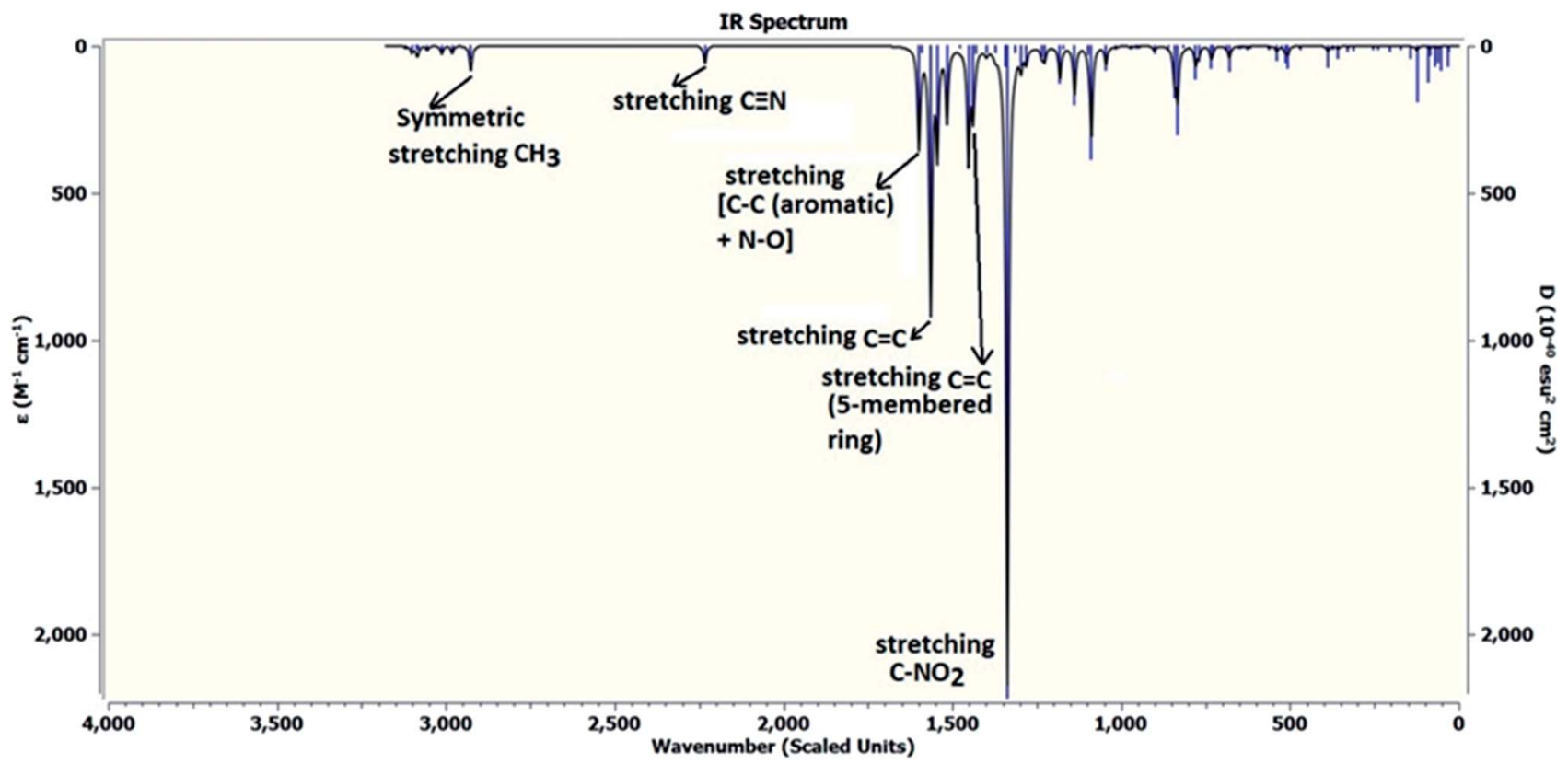

Fig. 13 Theoretically obtained infrared (IR) spectrum of the (Z)-isomer by DFT calculations.

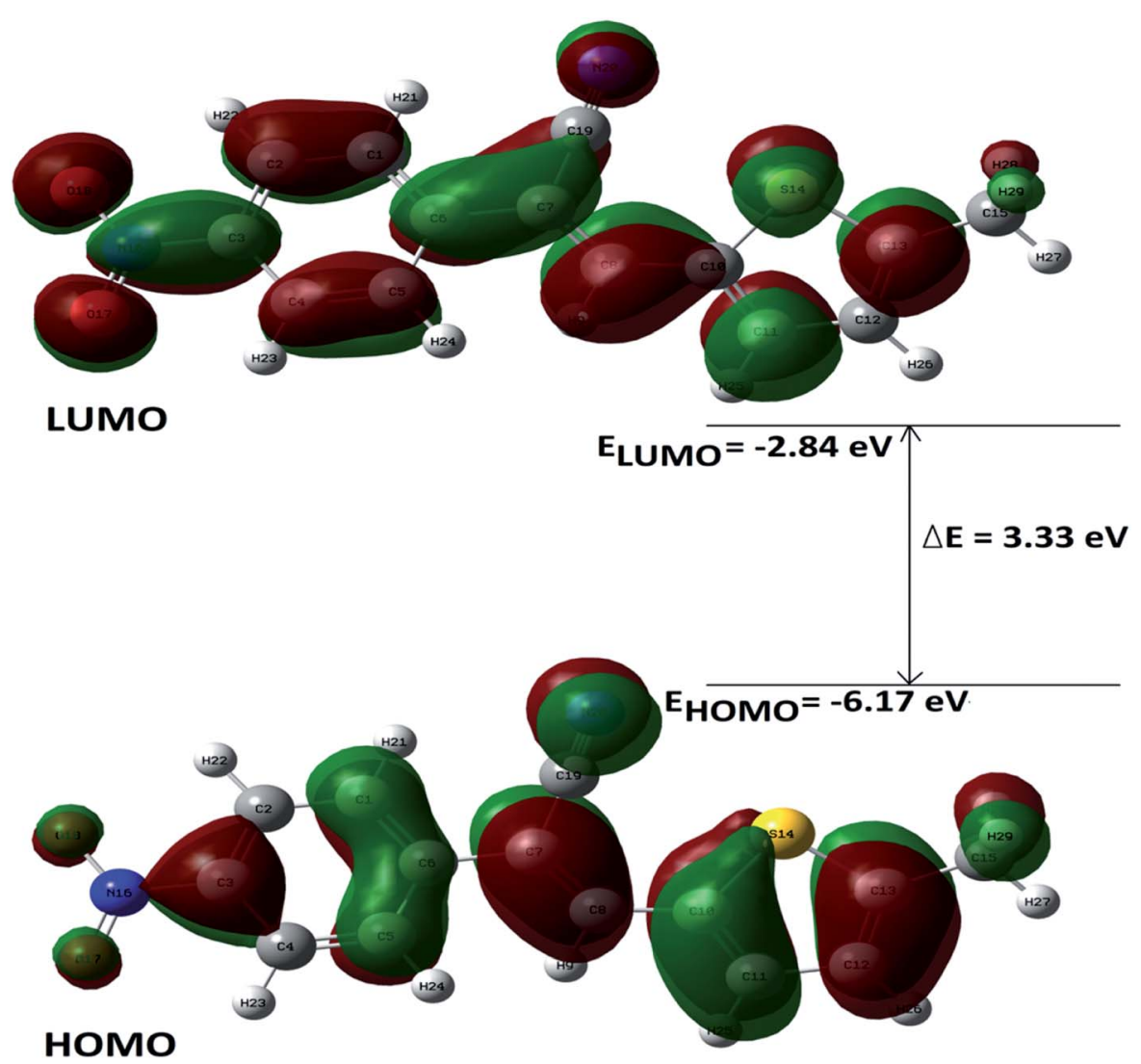

Fig. 14 Electron density distributions in the (a) HOMO and (b) LUMO of the (Z)-isomer. 
as obtained was filtered and immersed in DMF $(100 \mathrm{~mL})$ and kept overnight. It was then filtered again and immersed in $\mathrm{CHCl}_{3}$ (100 mL, HPLC grade). The solvent was exchanged 3 times over 7 days: after 2 days, 3 days, and 7 days. The bulk of the solvent was decanted; the product was evacuated overnight and activated at $150{ }^{\circ} \mathrm{C}$ for $24 \mathrm{~h}$.

\section{Synthesis of S-IRMOF-3}

To a magnetically stirred mixture of IRMOF-3 $(1 \mathrm{~g})$ in $\mathrm{CHCl}_{3}(20$ $\mathrm{mL})$, chlorosulfonic acid $(0.5 \mathrm{~mL})$ was added dropwise at $0{ }^{\circ} \mathrm{C}$. After the addition was complete, the mixture was stirred for $2 \mathrm{~h}$ until all $\mathrm{HCl}$ was removed from the reaction vessel. The mixture was then filtered, washed with methanol $(20 \mathrm{~mL})$ and dried at room temperature to give S-IRMOF-3 as white fine powder.

\section{Determination of $\mathrm{H}^{+}$ion concentration of S-IRMOF-3}

The $\mathrm{H}^{+}$ion concentration of the catalyst was determined by neutralization titration. $100 \mathrm{mg}$ of S-IRMOF-3 was stirred in $20 \mathrm{~mL}$ of $0.1 \mathrm{~N} \mathrm{NaOH}$ solution for $30 \mathrm{~min}$ in an Erlenmeyer flask. The excess amount of base was then neutralized by the addition of $0.1 \mathrm{~N} \mathrm{HCl}$ solution to the equivalence point of titration. The $\mathrm{H}^{+}$ion concentration was found to be $0.33 \mathrm{meq}$. $\mathrm{g}^{-1}$.

\section{General procedure for the synthesis of acrylonitrile derivatives}

To a mixture of substituted aromatic and hetero-aromatic aldehydes (1a-o) (1 mmol) and p-nitrophenylacetonitrile (2) (1 $\mathrm{mmol}$ ) in ethanol (5 mL) was added S-IRMOF-3 $(200 \mathrm{mg})$. The reaction mixture was refluxed at $90{ }^{\circ} \mathrm{C}$ for $30 \mathrm{~min}$. After completion of the reaction, as evident from TLC, the formed solid was filtered and washed with hot methanol to recover the catalyst. The filtrate containing a soluble product was evaporated under reduced pressure to obtain a crude product. The crude product obtained was washed with appropriate solvents, filtered, dried and crystallized from appropriate solvents. The catalyst was reused without a significant reduction of product yield.

\section{Conflicts of interest}

There are no conflicts to declare.

\section{Acknowledgements}

The authors would like to acknowledge DRS II (UGC, New Delhi), Department of Physics, AMU, for DFT analysis, University Sophisticated Instrument Facility (USIF), AMU, Aligarh, for SEM-EDX and TEM facilities, NCL Pune for ${ }^{13} \mathrm{C}$ MAS NMR analysis, IIT Madras for TPD- $\mathrm{NH}_{3}$ and SAIF Punjab for providing NMR and mass spectra.

\section{References}

1 L. D. Bonifacio, B. V. Lotsch, D. P. Puzzo, F. Scotognella and G. A. Ozin, Adv. Mater., 2009, 21, 1641-1646.
2 H. C. Zhou, J. R. Long and O. M. Yaghi, Chem. Rev., 2012, 8, 673-674.

3 M. Bardosova, M. E. Pemble, I. M. Povey, R. H. Tredgold and D. E. Whitehead, Appl. Phys. Lett., 2006, 89, 093116.

4 R. Stine, J. T. Robinson, P. E. Sheehan and C. R. Tamanaha, Adv. Mater., 2010, 22, 5297-5300.

5 (a) G. Férey, Chem. Soc. Rev., 2008, 37, 191-214; (b) J. R. Long and O. M. Yaghi, Chem. Soc. Rev., 2009, 38, 1213-1214; (c) T. R. Cook, Y. R. Zheng and P. J. Stang, Chem. Rev., 2012, 113, 734-777.

6 (a) D. Farrusseng, S. Aguado and C. Pinel, Angew. Chem., Int. Ed., 2009, 48, 7502-7513; (b) J. Lee, O. K. Farha, J. Roberts, K. A. Scheidt, S. T. Nguyen and J. T. Hupp, Chem. Soc. Rev., 2009, 38, 1450-1459.

7 W. Zhu, C. He, X. Wu and C. Duan, Inorg. Chem. Commun., 2014, 39, 83-85.

8 F. X. L. I. Xamena, A. Abad, A. Corma and H. Garcia, J. Catal., 2007, 250, 294-298.

9 L. T. Nguyen, C. V. Nguyen, G. H. Dang, K. K. Le and N. T. Phan, J. Mol. Catal. A: Chem., 2011, 349, 28-35.

10 P. Li, S. Regati, R. J. Butcher, H. D. Arman, Z. Chen, S. Xiang, B. Chen and C. G. Zhao, Tetrahedron Lett., 2011, 52, 62206222.

11 A. Dhakshinamoorthy, M. Alvaro and H. Garcia, Adv. Synth. Catal., 2010, 352, 711-717.

12 M. Opanasenko, M. Shamzhy, M. Lamač and J. Čejka, Catal. Today, 2013, 204, 94-100.

13 S. Gao, N. Zhao, M. Shu and S. Che, Appl. Catal., A, 2010, 388, 196-201.

14 M. J. Vitorino, T. Devic, M. Tromp, G. Férey and M. Visseaux, Macromol. Chem. Phys., 2009, 210, 1923-1932.

15 G. Férey, Chem. Soc. Rev., 2008, 37, 191-214.

16 (a) J. R. Long and O. M. Yaghi, Chem. Soc. Rev., 2009, 38, 1213-1214; (b) S. Kitagawa, R. Kitaura and S. I. Noro, Angew. Chem., Int. Ed., 2004, 43, 2334-2375.

17 J. L. Rowsell and O. M. Yaghi, Microporous Mesoporous Mater., 2004, 73, 3-14.

18 X. Kang, H. Liu, M. Hou, X. Sun, H. Han, T. Jiang, Z. Zhang and B. Han, Angew. Chem., Int. Ed., 2016, 55, 1080-1084.

19 (a) B. Karimi and D. Zareyee, Tetrahedron Lett., 2005, 46, 4661-4665; (b) B. Karimi and D. Zareyee, Tetrahedron Lett., 2005, 46, 4661-4665; (c) B. Das, K. Venkateswarlu, M. Krishnaiah and H. Holla, Tetrahedron Lett., 2006, 47, 7551-7556; (d) S. Shylesh, S. Sharma, S. P. Mirajkar and A. P. Singh, J. Mol. Catal. A: Chem., 2004, 212, 219-228.

20 D. Margolese, J. A. Melero, S. C. Christiansen, B. F. Chmelka and G. D. Stucky, Chem. Mater., 2000, 12, 2448-2459.

21 W. Van Rhijn, D. De Vos, B. Sels and W. Bossaert, Chem. Commun., 1998, 3, 317-318.

22 J. G. Shen, R. G. Herman and K. Klier, J. Phys. Chem. B, 2002, 106, 9975-9978.

23 R. van Grieken, J. A. Melero and G. Morales, Appl. Catal., A, 2005, 289, 143-152.

24 B. Rác, A. Molnar, P. Forgo, M. Mohai and I. Bertóti, J. Mol. Catal. A: Chem., 2006, 244, 46-57.

25 J. A. Melero, R. Van Grieken, G. Morales and V. Nuño, Catal. Commun., 2004, 5, 131-136. 
26 I. K. Mbaraka and B. H. Shanks, J. Am. Oil Chem. Soc., 2006, 83, 79-91.

27 A. Carta, P. Sanna, M. Palomba, L. Vargiu, M. La Colla and R. Loddo, Eur. J. Med. Chem., 2002, 37, 891-900.

28 K. M. Dawood, N. M. Elwan, A. A. Farahat and B. F. Abdel-Wahab, Synthesis, J. Heterocycl. Chem., 2010, 47, 243-267.

29 A. Carta, M. Palomba, G. Boatto, B. Busonera, M. Murreddu and R. Loddo, Il Farmaco, 2004, 59, 637-644.

30 J. Quiroga, D. Cobo, B. Insuasty, R. Abonía, M. Nogueras, J. Cobo, Y. Vasquez, M. Gupta, M. Derita and S. Zacchino, Arch. Pharm., 2007, 340, 603-606.

31 M. Hranjec, G. Pavlović, M. Marjanović, M. Kralj and G. Karminski-Zamola, Eur. J. Med. Chem., 2010, 45, 24052417.

32 F. Sączewski, A. Stencel, A. M. Bieńczak, K. A. Langowska, M. Michaelis, W. Werel, R. Hałasa, P. Reszka and P. J. Bednarski, Eur. J. Med. Chem., 2008, 43, 1847-1857.

33 P. Sanna, A. Carta and M. E. R. Nikookar, Eur. J. Med. Chem., 2000, 35, 535-543.

34 H. M. F. Madkour, Chem. Pap., 2002, 56, 313.

35 W. Kuzmierkiewicz, H. Foks and M. Baranowski, Sci. Pharm., 1985, 53, 133-138.

36 P. Sanna, A. Carta, L. Gherardini and M. E. R. Nikookar, Il Farmaco, 2002, 57, 79-87.

37 M. Parveen, A. M. Malla, M. Alam, M. Ahmad and S. Rafiq, New J. Chem., 2014, 38, 1655-1667.

38 L. Quattara, M. Debaert and R. Cavier, Farmaco, Ed. Sci., 1987, 42, 383-396.

39 A. Repicky, S. Jantova and L. Cipak, Cancer Lett., 2009, 277, $55-63$.

40 L. W. Yi, X. Q. Hai, M. Y. Xiang, L. Y. Min, D. N. Li and G. D. Peng, J. Org. Chem., 2001, 625, 128-131.

41 S. El-Tamany, F. W. Raulfs and H. Hopf, Angew. Chem., Int. Ed. Engl., 1983, 22, 633-634.
42 J. Masllorens, M. Moreno-Mañas, A. Pla-Quintana, R. Pleixats and A. Roglans, Synthesis, 2002, 1903-1911.

43 G. Thirupathi, M. Venkatanarayana, P. K. Dubey and K. Y. Bharathi, Der Pharma Chem., 2012, 4, 1897-1901.

44 (a) R. A. Rather and Z. N. Siddiqui, J. Org. Chem., 2018, 868, 164-174; (b) S. Siddiqui, M. U. Khan and Z. N. Siddiqui, ACS Sustainable Chem. Eng., 2017, 5(9), 7932-7941; (c) M. U. Khan and Z. N. Siddiqui, ACS Omega, 2018, 3(8), 10357-10364; (d) S. Siddiqui and Z. N. Siddiqui, Catal. Lett., 2018, 148(12), 3628-3645; (e) M. U. Khan and Z. N. Siddiqui, ACS Omega, 2019, 4, 7586-7595.

45 M. Zhao, K. Deng, L. He, Y. Liu, G. Li, H. Zhao and Z. Tang, J. Am. Chem. Soc., 2014, 136, 1738-1741.

46 (a) L. Lili, Z. Xin, G. Jinsen and X. Chunming, Green Chem., 2012, 14, 1710-1720; (b) J. A. Greathouse and M. D. Allendorf, J. Phys. Chem. C, 2008, 112, 5795-5802.

47 H. Sun, H. Su, X. Ma, P. Zhang, X. Zhang, X. Dai, J. Gao, C. Chen and S. G. Sun, Electrochim. Acta, 2016, 205, 53-61.

48 R. M. Abdelhameed, L. D. Carlos, A. M. Silva and J. Rocha, Chem. Commun., 2013, 49, 5019-5021.

49 D. Elhamifar, M. Nasr-Esfahani, B. Karimi, R. Moshkelgosha and A. Shábani, ChemCatChem, 2014, 6, 2593-2599.

50 N. T. Phan, T. T. Nguyen, Q. H. Luu and L. T. Nguyen, J. Mol. Catal. A: Chem., 2012, 363, 178-185.

51 E. Rahmani and M. Rahmani, Ind. Eng. Chem. Res., 2017, 57, 169-178.

52 T. C. Su, Z. Fang, F. Zhang, J. Luo and X. K. Li, Sci. Rep., 2015, $5,17538$.

53 M. J. Frisch, G. W. Trucks, H. B. Schlegel, G. E. Scuseria, M. A. Robb, J. R. Cheeseman, G. Scalmani, V. Barone, B. Mennucci and G. A. Petersson, et al., Gaussian 09, Gaussian. Inc., Wallingford CT, 2009, vol. 121, pp. 150-166.

54 L. M. Huang, H. T. Wang, J. X. Chen, Z. B. Wang, J. Y. Sun, D. Y. Zhao and Y. S. Yan, Microporous Mesoporous Mater., 2003, 58, 105. 